\title{
COMPUTER ANALYSIS OF THERMOGRAMS IN VERTEBRAL COLUMN PATHOLOGY AMONG THE CHILDREN
}

\author{
Robert Koprowski ${ }^{1}$, Henryk Konik ${ }^{2}$, Zygmunt Wróbel ${ }^{1}$ \\ 1 - Uniwersytet Śląski, Wydział Techniki, 41-200 Sosnowiec ul. Śnieżna 2 \\ 2 - Katedra i Klinika Akademii Medycznej we Wrocławiu, 50-370 Wrocław ul. 1 Maja 8
}

\begin{abstract}
s
In the article a special program for assessment of early stages of vertebral column deformities ( scoliosis) is presented. Analysis algorithm and graphic interface were implemented into Matlab environment using Real Time Workshop, Image Processing and Neural Network.
\end{abstract}

\section{Preface}

Vertebral column deformities occur in $3 \%$ of the children and teenagers population and are a serious diagnostic, therapeutic and economic problem. Commonly used diagnostic methods are based on X-rays which is harmful to patients health. Fotogramometric methods although harmless are however not enough precise. Independently of scoliosis ethiology in every case can be observed disorder of paravertebral muscles tension balance on both side of the vertebral column. It causes the metabolic changes of muscle tissue which lead to changes of the working muscle temperature [1, 2, 3, 7, 14]. In consequence of already mentioned we attempted to create a new diagnostic method of vertebral column deformities based on thermographic measurements of paravertebral region. Analysis of the obtained images requires sophisticated computer processing what makes the methods very precise and objective.

\section{Measurements}

Groups of 200 healthy and 100 sick patients in the age between 10 to 17 years old from such regions of Poland as Zakopane, Cieszyn, Wrocław, Mikołów were examined. Images were obtain with thermographic camera type AGEMA 470 with optical resolution $140 \times 140$ pixels in a room where temp. was $21 \pm 0,5^{\circ} \mathrm{C}$. Patients before examination spent over 20 minutes in the waiting-room slipped to the waist. Air streams convection in the examining room was restricted and the influence of all heat sources was eliminated. The camera was placed on the stand in the distance about $2 \mathrm{~m}$ from a patient. Patients stood undressed with their back to the camera, upper limbs were abducted and the trousers were lowered to the half of the nates. Spinous process of vertebra C7 (cervical) and L5 (lumbar) were marked on the back of each patient.

\section{Image processing}

Based on theoretical conditions relating to temperature distribution in paravertebral regions and their relationships with spinal column curvatures one may suppose that the temperature is higher on the concave side of the scoliosis. According to this and to analysis of mechanical instruments work the relationship between the scoliosis and differences in temperature distributions on both side of vertebral column may be expected $[4,6,8,9,10]$.

It is necessary to average temperature distributions on the left and right side of the vertebral column in a certain region and to calculate temp. change longwise its vertical axis. Because of this analysis of X-ray pictures and thermographic images became essential.

To image processing Matlab pack were used with its tools:

- Real Time Workshop- real time connection to external hardware; 
- Image Processing- working on images

- Neural Network- training the network using which the vertebral column position on the Xray picture was locate

\subsection{X-ray picture processing}

The following operations were performed on X-ray picture using scanner type PFU

DL2400 pro

- Image acquisition

- Histogram alignment

- Low-pass filtration

- Vertebral column shape detection

The last operation of vertebral column shape marking is realised using feedforward backpropagation network $[11,12,13]$. This network had been trained earlier and was used here in ready-made form. The examples of network activity are shown on the picture Pict.1.

\subsection{Thermogram processing}

Image from the camera is transferred to the PC with floppy disk or video connection. Initially image format *.img or *.ana is introduced to Matlab environment and coverted to the matrix form which elements are temperature values assigned to single pixels. On such image following operations are performed completely automatically:

- Filling the background with patient average temp. value- it enables the usage of entire colour map.

- Image binarization with lower threshold

- Object gravity centre calculation

- Marks location on patient back

- Location of the vertebral column shape on thermogram as a black line

- Average value calculation from paravertebtal regions on both side of placed vertebral column shape.

\section{Program description}

Complete image processing and verification of the data were performed using the author's program written in Matlab which main window is shown on pict. 2

Presented program enables :

- edition of image recorded with AGEMA camera 470 and 590

- basic image processing e.g.- fragment cutting, filtration or changing colour palette.

- marking vertebral column course manually or automatically based on X-ray pictures

- placing of vertebral column course on thermogram manually when there are no markers or automatically when they are present

- marking vertebral column course when there is no X-ray picture

- calculation and drawing average temp. value on both side of vertebral column which is an average value of $n$ pixels for each horizontal line on both side of marked regions.

- calculation of area value under the curve which is the difference previously calculated average values

- saving of the calculations and processed images

In automatic mode of vertebral column course marking the completely automatic work of program, when whole sequences of images are analysed, is possible. In such case it is necessary to give the range of analysed pictures and placing the markers on the patient body for thermographic image. 


\section{Clinical conclusions}

3 typical scoliosis case with temp. distribution analysis are shown on pict.3

From the presented on the pict.3-a average temp. value course, the crossing of both courses which occurs always in the inflexion point of the scoliosis is very characteristic ( green colour- right side, red one- left side). Another significant element is the difference of temperature on both side of vertebral column, always higher on concave side of the scoliosis.

\section{Analysis errors}

Error in average temp. values calculation is the result of finite optical resolution of the image ( $140 \times 140$ pixels), temp. resolution of the camera $\left(0,1^{\circ} \mathrm{C}\right)$ and inaccuracy in vertebral column course marking. Based on this and on analysis presented in [5] total error of average temp. values calculations can be estimated on $10 \%$ level.

\section{Summary}

Presented system advantages:

- non-invasive assessment of early scoliosis stage

- full automatics

- possibility of saving data to archives

\section{Grant N 4PO 5D 06715}

\section{REFERENCES}

[1] Ammer K.: Tetmography of neuromuscular disorders. Thermol. Osterr. 19993,3,18-23

[2] Anbar M.: A mechanistic explanatio of the correlation between inflammation, manifested of local hyperthermia and local pain. Thermol. Osterr. 1997,7,74

[3] Hoffman R.M, kent D.L.,Deyo R.A.: Diagnostic acceracy and clinical utility of thermography for lumbar radiculopaty, Spine 1991, 16, 623-628

[4] Image Processing Tolbox: User's Guide, Version 2, For Use with Matlab 1993-1997 MathWorks.

[5] Koprowski R., Wróbel Z Analiza błędów występujących przy pomiarach związanych z przetwarzaniem obrazu cz. I CCIATE

[6] Koprowski R., Wróbel Z.: Simulation of object of man on the ground of measurements obtained in hydropathy ASIS 99

[7] Lang E., Magerl W., Handwerker H.O Naundorfer B.: Thermografical evaluation of sympathettic reflexes and neurogenic vasodilation after traumatic transsection of the median nerve. Thermol. Osterr. 1997,7,81.

[8] Pavlidis T.: Grafika i przetwarzanie obrazów, WNT, Warszawa 1987.

[9] Tadeusiewisz R., Flasiński M., Rozpoznawanie obrazów, PWN, Warszawa 1991.

[10] Tadeusiewisz R., Korohoda P.: Komputerowa analiza i przetwarzanie obrazu, Społeczeństwo Globalnej Informacji FPT, Kraków 1997.

[11] Using Matlab: Graphics, User's Guide, Version 5, For Use with Matlab 5.2 MathWorks.1996.

[12] Using Matlab: User's Guide, Version 5, For Use with Matlab 5.2 MathWorks 1996.

[13] Zalewski A., Cegieła R.: Matlab - obliczenia numeryczne i ich zastosowania, PWM, Poznań 1997.

[14] Żuber J., Jung A.: Metody termograficzne w diagnostyce medycznej, Wydawnictwo Bramar, Warszawa 1997. 

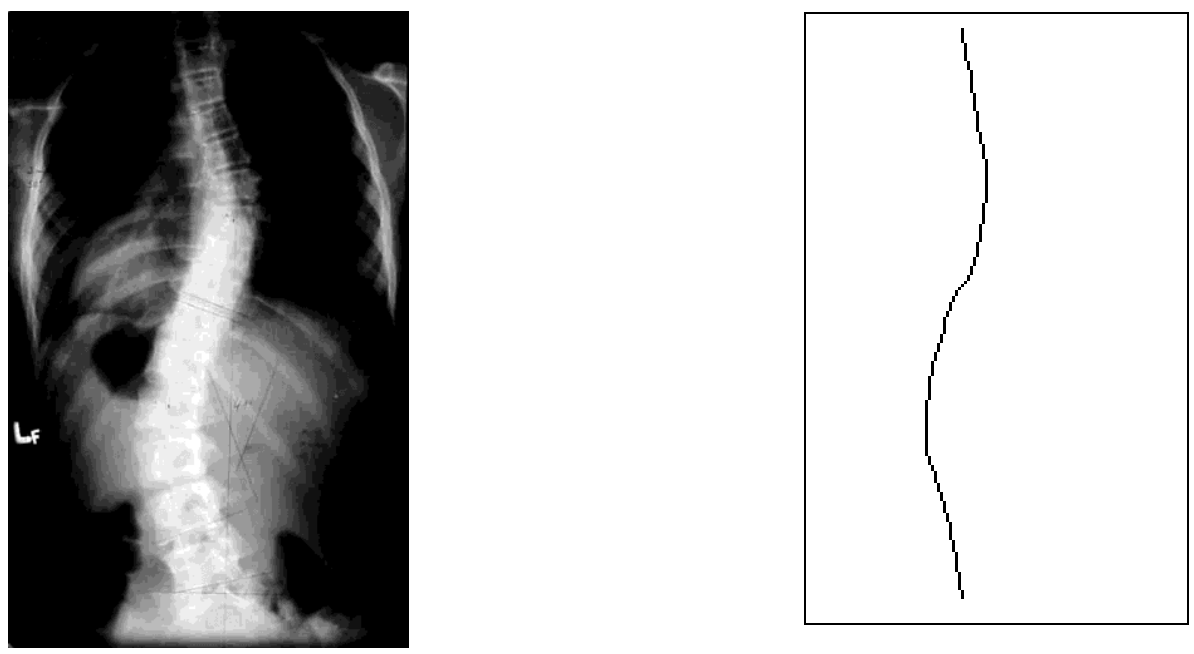

Pict.1 Marking of the vertebral column centre using neural network

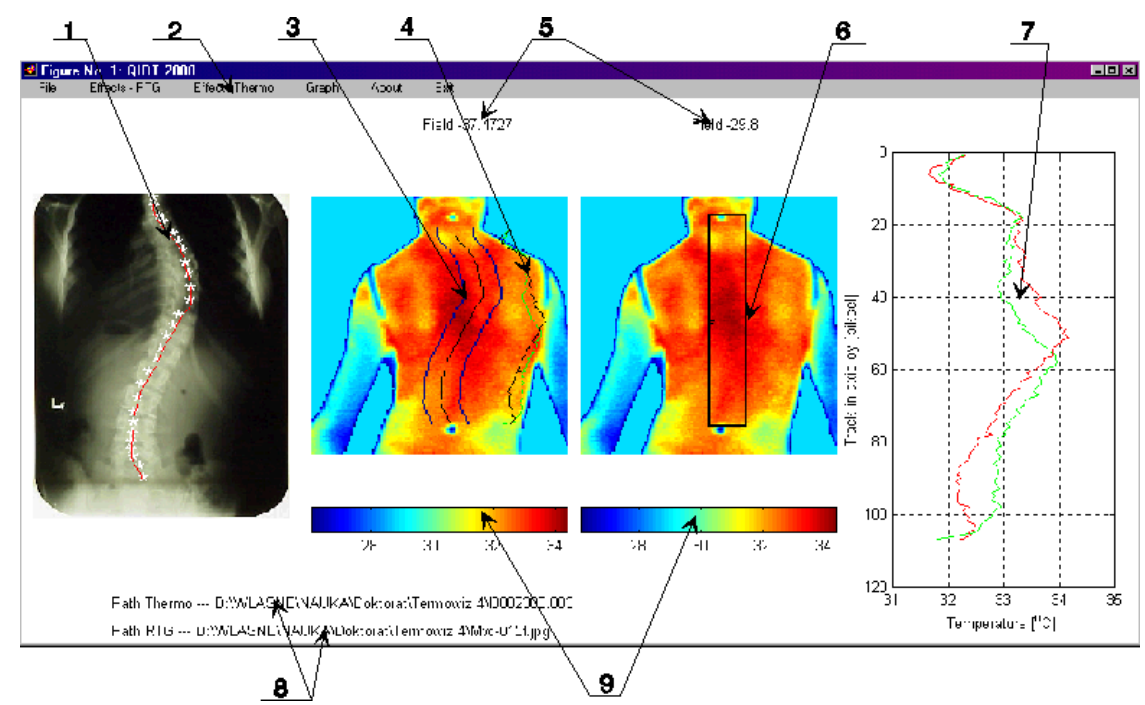

Pict. 2. Program main menu: 1) marked vertebral column course, 2) menu for saving, opening and working on images, 3) vertebral column course with lines limiting analysed pixels to average values, 4) and 7) average values diagram of both sides of analysed region on the left and right side, 5) area value under the difference of courses curve 7,6 ) automatically marked range of vertebral column course, 8) access paths to images, 9) colour palette "jet" type in which images were shown. 

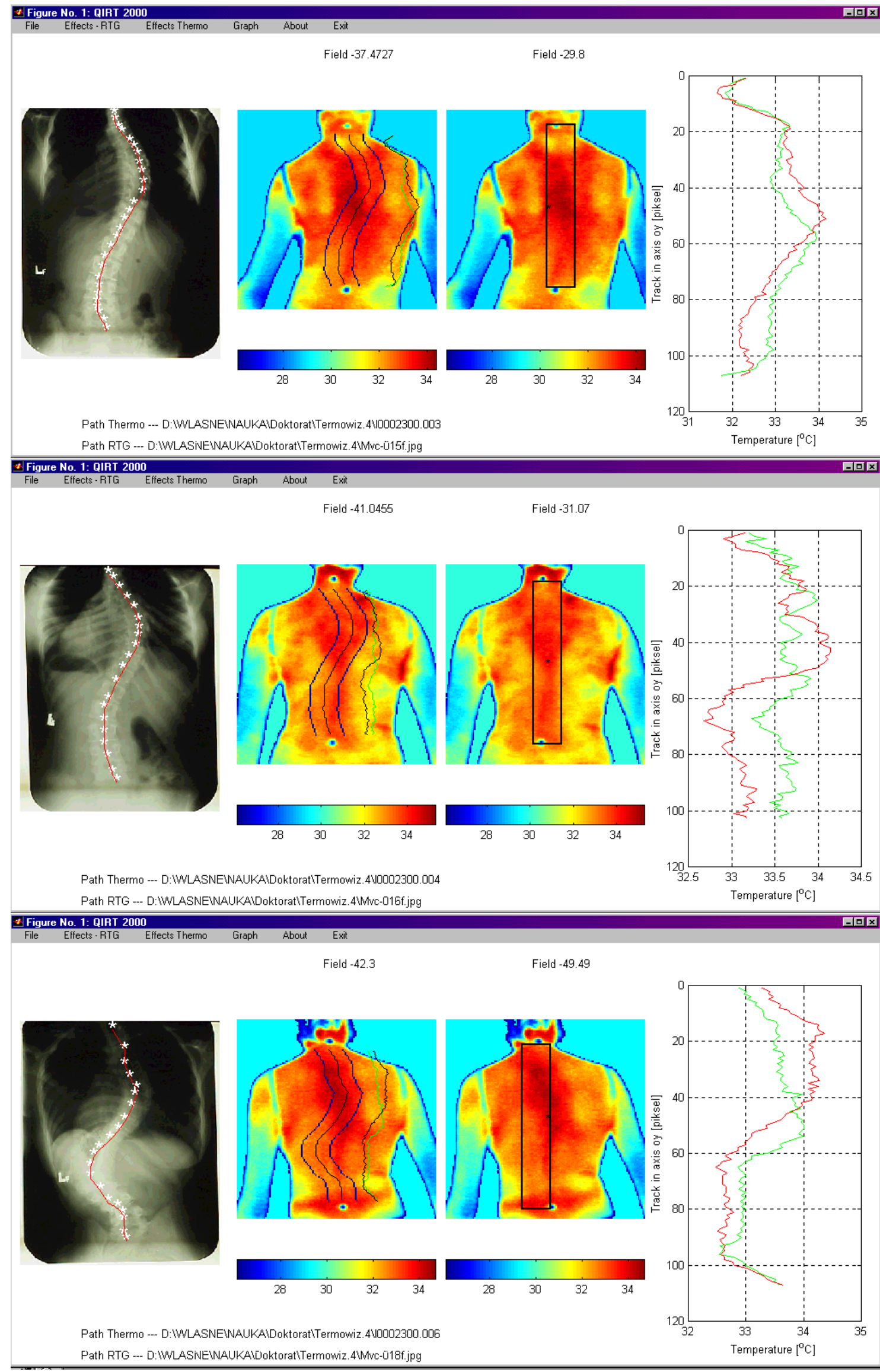

Pict. 3 Examples of scoliosis analysis in different cases of pathology. 